\title{
Colon Hodgkin Lymphoma
}

National Cancer Institute

\section{Source}

National Cancer Institute. Colon Hodgkin Lymphoma. NCI Thesaurus. Code C5499.

An extranodal Hodgkin lymphoma that arises from the colon. 